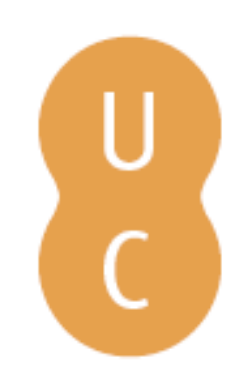

\title{
nombalina
}

\section{The Alexandria of Philo in Philo of Alexandria}
Autor(es):
Alexandre Jr., Manuel
Edições Afrontamento; CITCEM - Centro de Investigação
Publicado por: Transdisciplinar «Cultura, Espaço e Memória»; Centro de Estudos
Clássicos e Humanísticos; Alexandria University; Imprensa da Universidade de Coimbra
$\begin{array}{ll}\text { URL } & \text { URI:http://hdl.handle.net/10316.2/36180 } \\ \text { persistente: } & \text { DOI:http://dx.doi.org/10.14195/978-989-26-0966-9_14 }\end{array}$
Accessed : $\quad$ 26-Apr-2023 01:02:34

A navegação consulta e descarregamento dos títulos inseridos nas Bibliotecas Digitais UC Digitalis, UC Pombalina e UC Impactum, pressupõem a aceitação plena e sem reservas dos Termos e Condições de Uso destas Bibliotecas Digitais, disponíveis em https://digitalis.uc.pt/pt-pt/termos.

Conforme exposto nos referidos Termos e Condições de Uso, o descarregamento de títulos de acesso restrito requer uma licença válida de autorização devendo o utilizador aceder ao(s) documento(s) a partir de um endereço de IP da instituição detentora da supramencionada licença.

Ao utilizador é apenas permitido o descarregamento para uso pessoal, pelo que o emprego do(s) título(s) descarregado(s) para outro fim, designadamente comercial, carece de autorização do respetivo autor ou editor da obra.

Na medida em que todas as obras da UC Digitalis se encontram protegidas pelo Código do Direito de Autor e Direitos Conexos e demais legislação aplicável, toda a cópia, parcial ou total, deste documento, nos casos em que é legalmente admitida, deverá conter ou fazer-se acompanhar por este aviso.

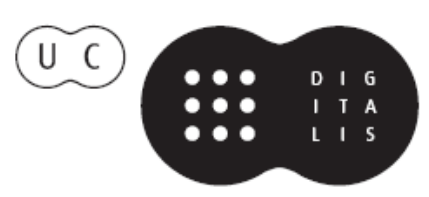




\title{
THE ALEXANDRIA OF PHILO IN PHILO OF ALEXANDRIA
}

\author{
MANUEL ALEXANDRE JR. \\ University of Lisbon. Centro de Estudos Clássicos (University of Lisbon).
}

\begin{abstract}
As we reflect on the Hellenistic Alexandria of education and culture, of sophistic rhetoric and philosophy, we need to focus our attention on the work of one of its most famous and distinct sons in the first decades of our Christian era. Though being few the explicit references in Philo's treatises to the city, the models of education and culture that emerge and take form in them are significantly numerous, if not even decisive to clarify the sophistic movement and its vitality in his time. We will center our attention in two topics: Alexandrian sophists under Philo's critical eyes, and the Alexandrian rhetoric in his philosophical education.
\end{abstract}

Philo lived in Alexandria when this capital of Hellenistic paideia was recognized in the Roman world as one of its main centers of higher education as well as of critical and literary production. The specific references he makes to the city are not many, but its implicit presence is almost a constant, not only in culture, art and the values that distinguish it, but also in their impact in the society of his time. We then ask ourselves: how did the Alexandrian philosopher see the city and its people? Which images he pictures of the models of education and culture it inspires? The origins of the Second Sophistic are still questioned today as well as the knowhow this movement represents in the training of the most cultured and learned representatives of this celebrated center of paideia by the beginnings of the 1st century B.C. A keener attention to thinkers like Philo on these matters would surely provide us 
a better understanding of the movement, once we can find in his treatises «a rich vein of information on the early 1 st century sophists» ${ }^{1}$.

\section{PHILO AND THE ALEXANDRIA OF HIS TIME}

Recognized as one of the most important centers of culture in Hellenistic Antiquity, Alexandria attracted the most learned masters of Hellenic education and became a prolific and radiating center of culture in the most expressive and universalizing meaning of the term. Not many decades after its foundation, this great metropolis of knowledge was being transformed in a meeting point of civilizations and cultures, in an authentic barn of the world; food not only for the body, but also and above all for the spirit ${ }^{2}$. Established in 290 B.C., the Library of Alexandria symbolically perpetuated the ecumenical dream of Alexander, attracting to the city a new elite of intellectuals, thinkers, sophists, philosophers, writers and specialists in philological and literary criticism ${ }^{3}$.

Rightly considered a second Athens, this Mediterranean pearl was above all distinguished by the singular diversity of its people; so propitious it was to the germinal configuration and reconfiguration of ideas. In the first decades of our era, the Museum still received and employed students from all origins, as in the glorious days of the Ptolemies. The great public library - «mirror of the soul and memory of the world» - continued being the inspiring center of culture in that important academy, as in the golden times of its highest splendor ${ }^{4}$.

The Jewish community was installed in Alexandria since its beginnings, and the signs of its presence were always increasingly visible until the foundations of our era, so important it was for the Hebrews as the cradle of the Bible in Greek and of flourishing Greek literature based in their traditions.

In the time of Philo, this important capital of Hellenistic culture was also the motherland of an essential part of the population who formed the Jewish diaspora. Tradition and Greek paideia converged in the education of the Jews who took advantage of the benefits of this authentic cultural golden age. The Jewish community was dispersed through the different strata of society, recognized among the rich and powerful as well as among the hum-

\footnotetext{
${ }^{1}$ WINTER, 2002: 240.

2 «Alexandria was the chief trading center in the Roman Empire. It shipped out enormous amounts of grain and luxury produce. Philo regularly names sailors and maritime merchants as well as fishermen in his occupation lists». He identifies pilots as «skilled people on whom lives depend»: And he names the common seamen «who had to labor at the oars when the wind was calm» (SLY, 1996: 83-84). Cf.: De plantatione 152; De Abrahamo 65; De virtutibus 49; De praemiis et poenis 33; In Flaccum $26,125$.

${ }^{3}$ JACOB, 1991: 23-24.

${ }^{4}$ Contrary to what is usually said, the library of Alexandria was not much affected by fire in the time of Julius Caesar. Cf. SLY, 1996: 39.
} 
ble and poor ${ }^{5}$. And two of the five administrative divisions were mainly occupied by Jews; which means that, in about five to six hundred thousand inhabitants, their community would not be far from one hundred eighty thousand ${ }^{7}$. Taking full advantage of the freedom granted for the exercise of their religious services and other social activities, the Jews had across the town many important synagogues; one of them being referred in the Talmud as follows: «who has not seen it, did not see for sure the glory of Israel $»^{8}$.

Totally immersed in the cultural environment of the land where he lived, Philo was distinguished among the most powerful and learned thinkers of his time, in no way inferior to the best of those who were nurtured with Hellenic paideia. Eusebius of Caesarea clearly says: «In regard to philosophy and the liberal arts of classical education, especially to his devoted study of Plato and Pythagoras... he surpassed all his contemporaneous»'. Although sparse in information on his life, Philo's evidence points to a man who was familiarly identified with the most flourishing strata of the Alexandrian society, distinguished amongst its members as a consummate thinker and a promoter not only of Hebrew wisdom but also of Hellenic philosophy and literature. As a credible source of information, Josephus mentions his brother Alexander the Alabarch as object of the greatest honors, and refers him as truly illustrious in the domains of philosophy ${ }^{10}$.

For this distinct Jew of the diaspora Alexandria was his home, his land, the place of his birth, education and mission as philosopher and educator of his own people ${ }^{11}$. The deep appreciation Philo had for this city can even be seen in the way he mentions the benefits the emperor Augustus provided with it: monuments that surpassed the most important art works of other imperial cities ${ }^{12}$. In the words of Pearce, «the importance of Alexandria as a great city in Philo's consciousness is revealed by the fact that Alexandria is the only earthly city he calls a $\mu \varepsilon \gamma \alpha \lambda$ ó $\pi \circ \lambda \iota \varsigma$ (great city), a word he normally uses to describe the cosmos» ${ }^{13}$. His description of the sea in front and its harbor ${ }^{14}$, the strategic position of the city, its lighthouse Pharos and central square ${ }^{15}$, the numerous monuments and palaces ${ }^{16}$ which occupied

\footnotetext{
${ }^{5}$ PEARCE, 2007: 8. As Pearce adds, «Philo gives no indication of how his family came to be in Alexandria... His sense of a profound attachment to Alexandria may point, however, to longer-established roots in the city. Philo's own commitment to his ancestral traditions speaks loud and clear throughout his writings... Philo's loyalty to the Jews of Alexandria and their local institutions... is concretely demonstrated by his role in the embassy of Gaius».

${ }^{6}$ De virtutibus 64; In Flaccum 55.

${ }^{7}$ Apparently inaccurate, the numbers advanced by Philo of Alexandria point to a million Jews in Egypt (In Flaccum 43 ).

${ }^{8}$ Sukkah 51b.

${ }^{9}$ Eus. HE 2.4.2-3. Cf. TAYLOR, 2003: 21-22.

${ }^{10}$ J. AI 18.159-160, 259; 19.276; 20.100.

${ }^{11}$ De vita contemplativa, 21; In Flaccum 2, 43, 45, 74, 163.

${ }^{12}$ Legatio ad Gaium 150.

13 PEARCE, 2007: 14.

${ }^{14}$ De somniis 2.143; De sacrificiis 90.

${ }^{15}$ De specialibus legibus 1.319-320; 3.105, 169, 171. De Abrahamo 20-21. Cf. Str. 17.1.10.

${ }^{16}$ Legatio ad Gaium 149-151; De ebrietate 177; In Flaccum 85.
} 
about one third of the geographical space as well as its secularr ${ }^{17}$ and religious life ${ }^{18}$, give us a lively and multifaceted image of the social and cultural lifestyle that was taking place there. Philo's sense of patriotism is especially visible in the reported sufferings of the Jews of Alexandria under Flaccus' administration ${ }^{19}$; mainly in climax, he adds:

But why were we to suffer such humiliations? When were we suspected of revolting? When were we not thought to be peacefully inclined to all? Were not our ways of living, which we follow day by day, irreproachable and inclined to good order and stability in the city? ${ }^{20}$

As a faithful son of his motherland and the culture he incarnated, the Alexandrian was, in the words of Arnaldez, «l'artisan principal de cette oeuvre gigantesque d'où est sortie toute la civilization occidentale: l'union intime du judaïsme et de l'hellénisme» ${ }^{21}$. And that could only happen in the soul of a great city like Alexandria. The monumental work of Philo represents, in fact, an unprecedented intellectual consummation made possible by the simultaneous convergence of the truths expressed by the wisest Greeks with those revealed in the sacred writings of Judaism. His matured knowledge of Greek literature, philosophy and culture in general, in all branches of Hellenic and Hellenistic education were surely acquired in the schools of Alexandria. In his treatises, he describes numerous times the different levels of instruction from the basics of learning and most elementary encyclical studies to the highest degrees of academic education, mainly in rhetoric and philosophy ${ }^{22}$. Perhaps it is Philo who helps us the most to perceive the dynamics of the sophistic movement in the 1st century A.D., including the beginnings of the most characteristically Asiatic phenomenon of the Second Sophistic.

If Philo's literary work had not been neglected for many centuries as it was, the traditional opinion that the Second Sophistic did not bloom until the end of the 1st century would have vanished long ago $^{23}$, and long ago what now seems so clear would have been accepted: that by the beginnings of the 1st century this movement already flowered or even flourished. That old tendency of interpretation and understanding of the origins of this phenomenon was in the meantime timidly questioned by Boulanger and vividly opposed by Bruce Winter. Referring Herod Atticus, Boulanger says that, «his school is just a partic-

\footnotetext{
${ }^{17}$ Legum allegoriae 2.85; De fuga et inventione 31-32; In Flaccum 136.

${ }^{18}$ De cherubim 92; De vita Mosis 2.28, 216; De specialibus legibus 1.2-11, 316, 319-320, 323; 3.40, 100-101, 171; De vita Mosis 2.14; De vita contemplativa 85; Quis rerum divinarum Heres sit 69; Legatio ad Gaium 82-83; Quod Deus sit immutabilis 17, 69; Hypothetica/Apologia pro Iudadeis 7.14.

${ }^{19}$ In Flaccum 55-72. Cf. PEARCE, 2007: 15.

${ }^{20}$ In Flaccum 94.

${ }^{21}$ ARNALDEZ, 1967: 14.

${ }^{22}$ De congressu eruditionis gratia 74-78. Cf. PEARCE, 2007: 17-18.

${ }^{23}$ "According to Filostratus, the "modern" period of the movement only really began in the reign of Nero» (WINTER, 2002: 2).
} 
ularly brilliant step of a slow and uninterrupted evolution, which has its origins in the times of Augustus ${ }^{24}$. Winter on the other hand maintains that this movement was already flourishing in the first part of the 1st century, especially in the cities of Alexandria and Corinth ${ }^{25}$, and that the traits that perform and inform the Second Sophistic movement were already verified in the Hellenistic paideia of the previous century.

In the same line of Boulanger, who says that sophistic was a symbol of Hellenism in the imperial centuries ${ }^{26}$, Giner Soria wisely sustains that the movement never ceased to be more or less markedly present in the Hellenistic and Hellenized world between the 5th century B.C. and the final end of Hellenism; that these educators and teachers were known everywhere for their most characteristic activity, the education of youth, and for the supreme investment of their art in speech composition and elaboration ${ }^{27}$; also that rarely a talented sophist limited himself to the simple office of teaching, assuming himself in full as a craftsman of the word put to the service of the social, civic and political community ${ }^{28}$; in Athens, as well as in the rest of the Hellenized world, and not only in Asia Minor.

In Alexandria, the Sophistic phenomenon was surely identical, with many teachers permeating the social tissue of the cities: sophists and rhetoricians as well as philosophers. Although Anderson reports the testimony of a student in the P. Oxy 2190 to support his argument on «the shortage of sophists» in Egypt by the second half of the 1st century ${ }^{29}$, the fact is that the expression used by Neilus might preferably mean that there was abundance of them, and those many, especially the good sophists, were not enough to satisfy the numerous solicitations of the most exacting. This explains his difficulty to find one, and

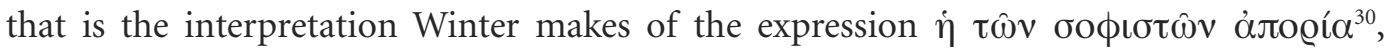
seemingly the most consentaneous with truth. In fact, Philo mentions «a large amount of sophists» teaching in Alexandria ${ }^{31}$, and Dion Chrysostom confirms it as he refers «an abundance of them $»^{32}$. Though Philostratus scarcely mentions them in the transition from the Roman Republic to the Empire, he does not omit among others the sophist Philostratus of Egypt «who studied philosophy with the queen Cleopatra» and was distinguished among others by his skillful speech and judicious reputation ${ }^{33}$.

\footnotetext{
${ }^{24}$ BOULANGER, 1923: 108.

${ }^{25}$ BOULANGER, 1923: 8. Winter uses these two cities as examples, as he clarifies the situation of the phenomenon: Alexandria in the first half of his work, and Corinth in the second (BOULANGER, 1923: 15-108, and 109-239 respectively).

${ }^{26}$ BOULANGER, 1923: 57.

${ }^{27}$ GINER SORIA, 1982: 27.

${ }^{28}$ GINER SORIA, 1982: 30.

${ }^{29}$ ANDERSON, 1993: 25.

${ }^{30}$ WINTER, 2002: 20.

${ }^{31}$ De agricultura 136.

${ }^{32}$ D. Chr. (Dion of Prusa) Oratio 32.11.

${ }^{33}$ Vidas dos sofistas 486.
} 


\section{THE ALEXANDRIAN SOPHISTS UNDER THE CRITICAL EYES OF PHILO}

All historians agree that, «the foundational trait of intellectual education in Alexandria... is its scholarly character», observes Arnaldez ${ }^{34}$. And he adds: «the grammatical and philological studies, rhetorical and philosophical, corresponded to precise programs for which manuals, anthologies and doxographies existed». The curriculum of the GrecoRoman schools of grammar and rhetoric was exemplarily followed in Alexandria, including a series of preparatory exercises of literary analysis and composition called $\pi \varrho \circ \gamma v \mu v \alpha ́ \sigma \mu \alpha \tau \alpha$; most of them being taught in those schools and made visible in the formal structures of his exegetical commentaries ${ }^{35}$.

The works of Theon of Alexandria precisely reflect this reality in the 1st century. His treatise of Elementary Exercises of Rhetoric is the best and most important rhetorical manual known of Alexandrian origin. And his exercises were programmed to provide to students and teachers a unified system of instruction, as a preparatory basis for higher courses of rhetoric and philosophy. These exercises were gradually qualifying the students for the intelligent and structured use of mind and word, for the analysis of model speeches and the consequent elaboration of their own discourses. Viscerally connected to the rhetorical tradition of Alexandria, Theon wrote other rhetorical treatises of no minor importance, but none of them survived to the erosion of time. This, however, is sufficient to underline the cultural and pedagogical labor of Alexandria, where two sophistic tendencies were being drawn in profile: that of those who, aligned with ancient orators like Isocrates, defended the necessity of studying philosophy as a basis for higher studies of rhetoric; and that of those who studied higher levels of rhetoric immediately after their training on the progymnasmata, valuing more their ability on the uttered word than competence on the logical reasoning of the logos born in the $\operatorname{mind}^{36}$.

The Progymnasmata of Theon on rhetoric represented in his time a correction attempt for the sophistical movement to recover its real face and to transform its model of education into a holistic science and art of knowledge that could combine philosophical and rhetorical training in the education of a really cultured man. This explains why the sophists were so important in the educational system of Alexandria, providing and promoting the conditions needed to accomplish in the society this noble cause of paideia.

The same pedagogical attitude was taken by Philo half a century before and with a similar purpose; mainly when he criticized a particular group of sophists for simplifying

\footnotetext{
${ }^{34}$ ARNALDEZ, 1961: 95.

${ }^{35}$ Cf. De congressu 74-77; De Cherubim 105; De agricultura 18; De somniis 1.25; Quaestiones et solutiones in Exodum 2.103: De congressu 11, 15-18; Quaestiones et solutiones in Genesim 3.21; De vita Mosis 1.23.

${ }^{36}$ A recurring problem in the history of sophist culture, and not only in the Hellenized Alexandria of the 1st century A.D. (cf. Isoc. 1-11).
} 
and swallowing the system, perhaps more taken by their wish of profit and fame than by their own concern with a fully integrated education philosophy.

The impact of Hellenistic education on the cultural environment of Alexandria was felt in the work of the promoters of sophistic rhetoric in such a way that it fertilized all genre of human discourse. This phenomenon is clearly verified in the way orators established their themes, structured their arguments and defended their theses, and in a time when conference rooms and theaters were overloaded with people who attentively watched eloquent orations on virtue and similar themes ${ }^{37}$. The evidence of such phenomenon in the works of Philo is thus crucial for understanding the importance of this movement in the city where he was born and lived all the time, and crucially opposes the belief that «there was an absence of rhetorical activity in Alexandria from the late Ptolemaic Period through to, and during, the movement called the Second Sophistic in the late first and second centuries A.D.» ${ }^{38}$.

The term «sophist», originally used to describe the sage, was used in the 1st century to designate the rhetorician skillful in rhetoric; the educator who was able not only to touch the heart of the hearers with his speeches, but also to attract disciples to his school. The sophist was intrinsically the master of eloquence who devoted himself to higher degrees of Hellenic paideia. Many of those teachers of rhetoric preferred, however, to be called rhetoricians, perhaps because of the unfavorable connotations the term «sophist» was attracting, per force of the unavoidable deflections to which this noble mission was being subjected ${ }^{39}$.

In the succinct words of Bowersock, a sophist is «a virtuous rhetor with a big public reputation ${ }^{40}$; in other words, a cultured orator (a pepaideumenos in action), competent in the art of speaking in public and able to develop, with greater or smaller degree of ostentation, a higher form of education predominantly rhetorical ${ }^{41}$. What then was expected from the sophist was for him to be a good educator of youth, skilled in the exegesis and interpretation of the great creative pieces of literature, a learned expert in rhetoric, competent to instruct his students in the art as well as in eloquence ${ }^{42}$.

The concept of «sophistic» is semantically so inclusive in the time of Philo that he

\footnotetext{
${ }^{37}$ SMITH, 1974: 71-72, 130.

${ }^{38}$ WINTER, 2002: 2. See this argument in FRASER, 1972: 810; also in TURNER, 1975: 5.

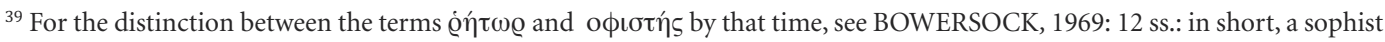
would be a rhetorician who attained a high degree of success in his art as educator and master of rhetoric. A teacher who specialized in the art of rhetoric, but not necessarily trained in philosophy.

${ }^{40}$ BOWERSOCK, 1969: 13.

${ }^{41}$ Cf. ANDERSON, 1993: 1.

42 The rhetoric of the first sophists was configured by the following principles: rationale of circumstances, ethics of competition, aesthetic of exhibition. They could not be understood only as specialists in ornamental oratory; because, itinerant educators and exceptional cultural leaders, the sophists were characterized by their versatility, but also by their determined Hellenism as authentic ambassadors of the Hellenic culture.
} 
sometimes calls sophists to the philosophers, to those speaking on philosophical themes ${ }^{43}$, and even to classical poets like Homer and Hesiod ${ }^{44}$. The rhetorical culture of the sophists is so relevant in his treatises and so frequently acute is his demarcation from the sophistic pattern that the images he uses talk by themselves, leaving us with the conviction that the two movements in tension were vividly felt in the Hellenistic paideia of Alexandria at the beginning of our Christian era. Such is the reason why the Alexandrian philosopher defends a rhetoric that is worth of the philosopher, a rhetoric that will change man into a consummate master of words in the utterance of the most sublime ideas, and not a defaced type of rhetoric proclaimed by a certain elite of clever sophistry ${ }^{45}$.

True sophistic paideia very early triumphed in the Roman Empire, developing an authentic literary culture in schools where the director was a sophist and «rhetorical imitation» creatively encouraged the reconfiguration of the models found in the best literature of Classical Antiquity ${ }^{46}$. Winter clearly shows its vitality in Alexandria by the time of Philo based on three primary sources ${ }^{47}$ : the Philonic corpus, which reflects the character of this movement in the first half of the 1st century; the Oratio 32 of Dion of Prusa ${ }^{48}$, which discussed the movement primarily in terms of relationship with public life; and a letter $(P$. Oxy. 1290) that a student of Alexandria called Neilus ${ }^{49}$ wrote to his father in the perspective of a student who learns Greek rhetoric with the sophists. From each one of these documents, we receive precious information on the activities of the philosophers, orators and sophists in the Alexandria of the 1st century A.D. and from them we conclude not only that the sophistic movement was solidly implanted in Alexandrian soil, but also that numerous sophists were then teaching in the city $^{50}$. So important was the sophistic presence in Alexandria in its diverse configurations that Philo directly or indirectly refers it over a hundred times, not to mention the numerous commentaries he also makes to the movement ${ }^{51}$. And,

\footnotetext{
${ }^{43}$ Cf. De congressu eruditionis gratia 67.

${ }^{44}$ Large was the variety of people who called themselves or were called sophists in Greek antiquity. This name was applied to poets, to musicians and rhapsodes, to diviners and seers, to wise men and philosophers like the pre-Socratics, to mathematicians and politicians. Cf. WOLFSON, 1962: 28. As Winter opportunely observes, Wolfson argues that Diogenes Laertius equally supports this identification, when saying that sophist was a different name given to important educators: to wise men, philosophers and poets. Cf. De providentia 1.43; De sacrificiis 78; De congressu 15, 74, 148; De agricultura 18; De somniis 1.205. 45 «On se souviendra que tout éloge de la rhétorique s'acompagne chez lui d'une mise en garde» (ALEXANDRE, 1967: 37. Cf. De congressu 17.

${ }^{46}$ CASSIN, 2000: 973.

47 WINTER, 2002: 5.

${ }^{48}$ D. Chr. Alexandrian Oration 32.68.

${ }^{49}$ P. Oxyrhynchus 2190.

50 WINTER, 2003: 38-39, 58.

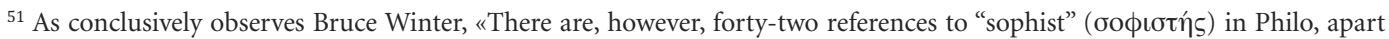
from fifty-two references to cognates, and numerous comments on the sophistic movement. His evidence constitutes the single most important witness for the first half of the 1st century on the Greek side, and nothing comparable exists elsewhere for this period in the empire» (2003: 7).
} 
we repeat, only an unfortunate inattention to these sources justifies the sparse references made to the Alexandrian by the scholars who have studied this rhetorical phenomenon in the Roman Empire ${ }^{52}$.

Although Philo of Alexandria usually mentions the term in a less positive sense to connote a deviant component of the Alexandrian sophists, he is careful enough to register the impact they had in the city for the admiration they got with the competence and technical value of their art. What Philo condemns is not the sophistic culture that philosophers and educators like Isocrates inspired ${ }^{53}$. With this Isocratic philosophy of discourse he was plainly identified. It is the bad use of it, the type of education being provided by the «ill educated in rhetoric», by those who exploited «the legitimate arts of speech or methods of persuasion not to defend the truth but to oppose it» ${ }^{54}$, the ones who were more eager to serve themselves and their own appetites than the students whose education they were paid for; rhetoricians who were supposed to be masters of virtue and roundly failed in the culture of the ethical ideal of Hellenic paideia; sophists who taught eloquence to seduce their students and not to honor truth with their teachings; ingenious masters of rhetoric more motivated by gain ambition than by the enrichment of their hearers in the pedagogical and ethical values of Hellenic paideia. These problems were always common among the sophists, even in the early times of Isocrates; problems against which this great Athenian educator was raising his voice without failing to be an illustrious and paradigmatic sophist ${ }^{55}$.

In Philo's Alexandria, as in the 4th century B.C., the most important characteristic of the sophists was thus that all of them taught rhetorical art in its best; a genuine sophistic paideia that, as a «true oasis of ideas», incarnated the sublime of Hellenic wisdom, and rhetorically nurtured «the theories of discourse, composition and argumentation» ${ }^{56}$. The real purpose of sophistic education was initially, and continued to be, the holistic shaping of a wise man competent in the art of thinking as well as in that of acting. However, with difficulty were these ideas anytime materialized into a univocal sophistic rhetoric; a rhetoric that united theory, practice and ideology in the configuration of speeches logically and argumentatively persuasive, structurally and figuratively expressive, and ideologically impregnated with an ethic of values truly human and universal.

\footnotetext{
52 See: SMITH, 1974: 130; KENNEDY, 1972: references to Philo, p. 452-453; references to Dion of Prusa: p. 566-582. In A New History of Classical Rhetoric (Princeton: Princeton University Press, 1994): reference to Philo, p. 186-187. BOWERSOCK, 1969: 20-21. ANDERSON, 1993: 203-205.

53 The Isocratic program of education, logon paideia, aimed at forming leaders of a high moral temper that could provide solid orientation and counsel in matters of civic value, relevance and effectiveness. The philosophy of discourse he taught was the philosophy of life he practiced.

${ }^{54}$ WINTER, 2002: 61-62.

55 Cf. Panegyricus 1-10.

${ }^{56}$ SCHIAPPA, 1999: 49. Quoting Jasper Neel, Schiappa adds: «Declaring himself a Sophist, Jaster Neel advocates 'Sophistical Rhetoric' as a study of how to make choices and a study of how choices form character and make good citizens»(Plato, Derrida, and Writing. Carbondale: Southern Illinois University Press, 1988, p. 211).
} 
Far from this conception of a univocal sophistic, would also be the schools of educators who impregnated the social Alexandrian tissue, some perhaps closer to Gorgias and others to Isocrates or even to Plato. But the fact is that the teaching of rhetoric, the teaching of eloquence and the education of the orator were closely related, with more or less ethical rigor, to form both the orator and the philosopher, the most astute politician and the most honest and faithful server of the polis. In the city, the sophist and the philosopher both cultured Hellenistic paideia, and both were prepared to teach rhetoric from the encyclical and most elementary typologies of rhetorical exercises to the highest levels of knowledge; that type of philosophy of the discourse aimed by the pepaideumenos, be it in search of the ultimate reality of being, be it in search of a consummate wise man who thinks well, talks well and acts well in behalf of his fellow-citizens in the construction of a higher well-being for all.

Instead of resisting to Greek paideia, Philo absorbed the essence of its contents ${ }^{57}$ and described all disciplines of encyclical education ${ }^{58}$, paying special attention to grammar, rhetoric and dialectic. Grammar - elementary and higher stages of studies, including writing and reading in the first part, and the study of literature in the second - is referred six times in his treatises as of great value for studying philosophy, able to develop intelligence as well to deepen knowledge ${ }^{59}$. Rhetoric - awakening the mind for the observation of facts, training and tempering the mind for the expression of its thoughts - will make man a true master of words and ideas, refining even more the peculiar and special gift that nature entrusted to man alone ${ }^{60}$. «Dialectic - a structured discipline designed to discover truth and falsity by probing into the particulars of the argument $\rangle^{61}$, and usually compared with logic as one of the three parts of Stoic philosophy -, is to Philo «the sister, the twin sister of rhetoric, distinguishing true argument and refuting the plausibilities of sophistry» ${ }^{62}$. In his understanding, those who accomplish the various stages of paideia but are not cultured in virtue, end becoming sophists in the worst meaning of the word. But the true rhetorician or sophist is necessarily "a master of virtues» ${ }^{63}$. And when he does not reach the goal of being so, easily fails confusing sustainable arguments with the magical seduction of words, and consciously or unconsciously permitting or even promoting the defeat of truth ${ }^{64}$.

\footnotetext{
${ }^{57}$ RUNIA, 1986: 35-36.

58 The eight individual disciplines of the $\dot{\varepsilon} \gamma x u ́ x \lambda \iota$ os $\pi \alpha \iota \delta \varepsilon i ́ \alpha$ that by the Middle Ages constituted the seven liberal arts ans sciences: the trivium, including grammar, rhetoric and dialectic; the quadrivium, including geometry, arithmetic, music, and astronomy. Cf. De congressu 74-77; De cherubim 105; De agricultura 18; De smomniis 1.205; Quaestiones Exodum 2.103; De cogressu 11, 15-18; Quaestiones Genesin 3, 21; De vita Mosis 1.23.

${ }^{59}$ De congressu 15, 74, 148-150; De agricultura 18; De ebrietate 49. De mutatione nominum 229.

${ }^{60}$ De congressu $17,69$.

${ }^{61}$ MENDELSON, 1982: 10-11.

${ }^{62}$ De congressu 18.

${ }^{63}$ De sobrietate $8-10$.

${ }^{64}$ De somniis 2.40; De praemiis et poenis 25; De gigantibus 59; De agricultura 96; Quis rerum divinarum heres sit 85, 302, 304-305 , etc.
} 


\section{ALEXANDRIAN RHETORIC IN THE PHILOSOPHICAL TRAINING OF PHILO}

The synagogues were in Alexandria the chosen centers of religious life of the Jews ${ }^{65}$. The Greek word to synagogue means «assembly», «congregation», a «house of prayer». And the religious activities that took place there were so important for the Jewish communities that Philo used to call them «schools» of wisdom and other virtues ${ }^{66}$. There were many synagogues in the city as meeting points of community life for the Jews and privileged learning centers of Jewish culture; houses of prayer, Bible teaching, communion and worship service, but also schools for basic instruction and the incarnation of essential principles and values for daily living in community.

Receptive to Hellenistic culture, the Jews of Alexandria used the Septuaginta ${ }^{67}$ for reading and exposing the Biblical texts, and forgot with time their own language, being thus encouraged, not to say forced, to attend the Greek schools. In the Gymnasium, they combined physical education with the encyclical studies of grammar and the elementary exercises of rhetoric ${ }^{68}$, jointly with dialectics, geometry, arithmetic, music and astronomy. In more advanced stages of learning, they could even be trained to the point of receiving degrees in the areas of rhetoric and philosophy as well as others in the scientific realm; especially members of rich families. Higher studies of rhetoric and philosophy were usually done in the schools of the sophists. And it was in fact the case of Philo.

A simple reading of Philo's writings immediately leaves us with the impression of a vast Hellenistic culture permeating his ideological universe and governing the expression of his own thought. The text flows more or less naturally in an impeccable Greek atticizing koine, through a copious and appropriate vocabulary. His evident knowledge of all genre of Greek literature is, for a Jew like him, impressive, quoting numerous times more than fifty different classical authors ${ }^{69}$.

The themes developed along his treatises are usually elaborated in conformity with «an ample variety of rhetorical techniques» ${ }^{70}$ and the productive clarity of his thought as well as his dense and articulate philosophical knowledge place him among the great thinkers of his time. The cultural environment of Alexandria and his exemplary education in the domains of Greek paideia justify it, the contents and literary structure of his work testify it and confirm it too.

\footnotetext{
${ }^{65}$ The epigraphic and papyrologic evidence of synagogues is abounding, in the inner city as well as in the suburbs. But detailed information on the worship services and the teaching of the Law that were taking place there comes to us through the work of Philo himself.

${ }^{66}$ De vita Mosis 2.215-216; De specialibus legibus 2.62-63.

${ }^{67}$ Greek version of the Jewish Bible, the LXX.

${ }^{68}$ Cf. MENDELSON, 1982: 2-3.

${ }^{69}$ SANDMEL, 1979: 15.

${ }^{70}$ WINSTON, 1981: 1.
} 
It might sound as nonsense to speak of sophistic rhetoric in Philo's philosophical training. But it was in fact rhetoric, in the Isocratic meaning of the term that has mainly contributed to his philosophical vocation as interpreter and commenter of Scripture: rhetoric as philosophy of discourse, conceived in the mind and born from it; the kind of rhetoric that, in his own words, "will transform man into a true master of words and thoughts» ${ }^{71}$.

What does Philo want to say with these words? Why is this type of mastery so important for him? The answer is found in Quod deterius 34-42. As we read in Mendelson,

virtuous men, such as Abel and Moses, find themselves in situations where verbal ability becomes a matter of vital importance. "Abel has never learned arts of speech ( $\tau \dot{\varepsilon} \chi v \alpha \iota$ $\lambda o ́ \gamma \omega v)$, and knows the beautiful and noble with the mind only» (Det. 37). Because Abel was not equipped to speak, Cain did not find it difficult «to gain the mastery over him by plausible sophistries» (Det. 1). Moses, on the other hand, wisely let his brother Aaron speak for him.

While Moses produced his speech in the mind, Aaron uttered and transmitted it to the people $\mathrm{e}^{72}$. What Aaron had and Abel did not have was then rhetorical competence; a technique that, in Philo's understanding, was urgent and necessary to orators as well as to philosophers to fight the sophistries of the Alexandrian orators; those who did not care to defending themselves with the shield of virtue and the noblest thoughts (Det. 41). For, as Philo asserts,

when we have been exercised in the forms which words take, we shall no more sink to the ground through inexperience of the tricks of the sophistic wrestling... But if a man though equipped in soul with all the virtues, has had no practice in rhetoric, so long as he keeps quiet he will win safety... but, when like Abel he steps out for a contest of wits, he will fall before he has obtained a firm footing (Det. 42).

The essential goal of rhetoric, adds Mendelson, «was not simply to develop superficial skills which any "clever wrestler» might acquire. Rather, its central goal was to insure that speech interpreted thought properly» ${ }^{73}$. In short, Philo fought for an art worthy of the philosopher, a rhetoric that would transform man into a consummate master in the expression of sublime ideas. The arguments he advances in Quod deterius 34-45 are clear and persuasive enough to show that. Even the wisest and most persuasive orator will unavoidably succumb if he fails having a genuine training in this art.

\footnotetext{
${ }^{71}$ De congressu 17.

72 MENDELSON, 1982: 7-8.

${ }^{73}$ Loc. cit.
} 
Comparing rhetoric with medicine and medical theory with clinical practice, he clarifies then the close relationship that should exist between wisdom and eloquence. In other words, rhetoric is as necessary to logic as clinical practice is to its theory, and vice-versa.

For, just as in medicine there are some practitioners who know how to treat almost all afflictions and illnesses and cases of impaired health, and yet are unable to render any scientific account either true or plausible of anyone of them; and some, on the other hand, who are brilliant as far as theories go, admirable exponents of symptoms and causes and treatment... but no good whatever for the relief of suffering bodies, incapable of making even the smallest contributions to their cure; in just the same way those who have given themselves to the pursuit of the wisdom that comes through practice and comes out in practice have often neglected expression, while those who have been thoroughly instructed in the arts that deal with speech have failed to store up in soul any grand lesson which they have learned. It is in no way surprising that these latter should discover an arrogant audacity in the unbridled use of their tongue. They are only displaying the senselessness that has all along been their study. Those others, having been taught as doctors would be, that part of the art which brings health to the sickness and plagues of the soul, must be content to wait, until God shall have equipped in addition the most perfect interpreter, pouring out and making manifest to him the fountains of utterance ${ }^{74}$.

In other words, rhetorical argumentation is as necessary to logic as is clinical practice to medical theory. For it is by the discipline of language that thought is expressed and the mind is able to mold into intelligible form its most beautiful ideas. Without it the philosopher would loose himself in a logomachy of abstract terms (De Opificio mundi 1). In Philo's understanding, those who practice rhetoric with no care for rigorous truth, place themselves in the basest plan of sophistry and are in risk of serving the cause of those who are against truth itself, so absorbed they are in arguing for the sake of argument, or in their passion for money.

What in the philosophical and rhetorical training of Philo made the difference was his frame of references and values, which since childhood nurtured his mind and heart, namely truth and virtue; also equated balance in his studies of rhetoric and philosophy in his ultimate pursuit of wisdom, to the point of conciliating both with excellence and developing the contours of his own philosophy of language - what is perfectly in tune with the values of Hellenistic paideia in its best and perhaps transcends it. Like Plato, he distinguishes true from false rhetoric, connoting philosophical rhetoric with the first and sophistic rhetoric with the second, and recognizing the propaedeutic value of the first as the one really indispensable to the education of man in its wholeness.

No doubt inspired in the Stoic and Isocratic concept of $\lambda$ ó $\gamma$ os as a distinct trait of

\footnotetext{
${ }^{74}$ Quod deterius 43-44.
} 
man and supreme gift of humanity, Philo stresses the ambivalence of the word and turns perfect human communication dependent from both of its semantic components: the mind or reason that suggests ideas, and the speech that utters them. This is the key observation he makes when tracing the symbolic picture of Abel and Cain as figures that represent thought and word as complementary aspects of the excellence of the same $\lambda$ ójos. This term represents in fact two twin brothers, one mental and the other verbal, the last one being the interpreter of the first. The rhetoric that Philo exemplifies in Moses and Aaron is, thus, the most convenient to the philosopher and the wise $\operatorname{man}^{75}$, a species of perfect rhet-

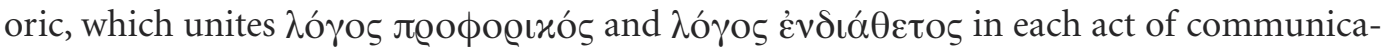
tion; that is, idea and word, reason and discourse. It is consequently a philosophical rhetoric, concomitantly rhetorical philosophy, which is ultimately accomplished as servant of a species of consummate philosophy usually called wisdom.

According to Philo, the authentic rhetorician is thus the incarnation of «a species of a «perfect synthesis» of wisdom and eloquence» ${ }^{76}$ - the wisdom incarnated in logical truth, and the eloquence that utters it suitably. The $\lambda$ ó ${ }^{\circ}$ s contained in the mind of the sage incarnates in the orator's discourse, in order to hermeneutically discern and communicate truth. And then the need to express the truth contained in the mind of the philosopher is more than a sufficient reason for the Alexandrian thinker to insist in the importance of a perfect dominion of rhetoric ${ }^{77}$.

Philo's matured reflections on rhetoric eloquently show the levels of education that support the structure of his rhetorical and philosophical competence. He mastered these two branches of knowledge as a paradigmatic example of the excellent rhetorical education provided in the city. And thus he used the most diverse structures of argumentation and proof in his exegetical commentaries as well as in the logical argumentation of a thesis or the elaborate development of a theme. It is difficult to find in the rhetorical conventions a typology of argumentation that Philo did not make use of or strategically did not adapt to his literary project ${ }^{78}$. He was in fact one of the most learned and illumined minds of Alexandria in the 1st century of our common era, a really learned product of that celebrated center of reception and irradiation of culture, recommended at all levels as the true capital of Hellenistic paideia; a center that continued inspiring the circulation of the most celebrated paradigms of learning and knowledge. The search for the sublime in knowledge should have been so high in this historical capital of culture that students like Neilus lamented the shortage of good sophists' schools to satisfy all needs (P. Oxy. 18-19), though they were many, according to Philo and Dion Chrysostom ${ }^{79}$.

\footnotetext{
${ }^{75}$ Moses, the trustee of divine thoughts; Aaron, the symbol of the uttered word and brother of the mind.

${ }^{76}$ MENDELSON, 1982: 8-9.

${ }_{77}$ Cf. Quod deterius potiori insidiari solet 122-123, 130-131; De sacrificiis Abelis et Caini 82-83, 85; De migratione Abrahami 82.

${ }^{78}$ ALEXANDRE JUNIOR, 1999: 248-249.

${ }^{79}$ Philo, Agr. 136; D. Chr. Oratio 32.11.
} 
The number of sophists in Alexandria was effectively high in the first decades of the 1st century AD, but apparently few were truly sophists in the ideal sense of the word, excellent in knowledge and effective in its expression. Philo of Alexandria profusely shows it in his audacious critique of the sophistic tradition. Were he not so much forgotten and neglected, and perhaps today we would be much more informed on the impact and evolution of this important phenomenon in that unique cultural capital of the Hellenized world. 